\title{
PENERAPAN METODE BERMAIN PERAN DALAM MENGEMBANGKAN KARAKTER DAN KECERDASAN LINGUISTIK PADA SISWA SMP KELAS VIII DI PASRAMAN PURNA LINGGA PONDOK GEDE
}

\author{
Oleh: \\ Erma Wahyu Utami \\ Jurusan Pendidikan Agama Hindu \\ Sekolah Tinggi Agama Hindu Dharma Nusantara Jakarta \\ Email: irmawahyu818@gmail.com
}

\begin{abstract}
This study discusses the learning method using the role playing method in Pasraman with the aim of developing Linguistic character and intelligence. This research was conducted in Pasraman Purna Lingga Pondok Gede. The background of this research is to develop learning methods to vary, because previously in Pasraman Purna Lingga using conventional methods or lecture methods. The lecture method is considered less attractive because students are only silent, listening and easily bored for the writer trying to apply the role playing method, where students participate actively in the learning process. This study uses a qualitative descriptive approach in which the data collection uses interview techniques, observation and documentation in the Purna Lingga Pondok Gede area. From the results of the study using the role playing method that is applied to students of Class VIII Middle School characters in students has developed well, by using simulations through drama scripts students can know and understand the characters that are in the Ramayana story and applied in everyday life. Whereas for linguistic intelligence class VIII students are already good at using language and fluent in talking about knowing the accuracy of intonation, pronunciation, facial expressions and fluent in delivering the drama script.
\end{abstract}

Keywords: Methods of Role Playing, Character, Linguistics

\section{Pendahuluan}

Pendidikan secara etimologi berasal dari kata "didik" yang dapat diartikan memelihara atau memberi tuntunan mengenai kecerdasan pemikiran seseorang di masa yang akan datang. Pendidikan dapat menentukan nasib seseorang di masa depan. Pendidikan yang akan membawa seseorang menjadi tahu, tentang ilmu 
pengetahuan, ketrampilan serta kreativitas diasah melalui suatu metode pendidikan tersebut. Melalui sebuah pendidikan maka seseorang bisa memilih hidupnya di jalan yang benar atau dalam agama Hindu disebut dengan wiweka.

Pendidikan adalah salah satu bentuk perwujudan kebudayaan manusia yang dinamis sarat akan perkembangan. Oleh karena itu, perubahan atau perkembangan pendidikan adalah hal yang memang seharusnya terjadi sejalan dengan perubahan budaya kehidupan.

Dalam dunia pendidikan yang diperlukan tidak hanya yang bersifat umum tetapi juga pendidikan yang berkaitan dengan moral dan etika peserta didik, yang salah satunya terbentuk dari adanya pendidikan agama. Pendidikan agama memegang peranan penting dalam membentuk karakter anak khususnya dalam hal pendidikan agama Hindu untuk peserta didik yang beragama Hindu. Pendidikan agama Hindu adalah Pendidikan melalui ajaran agama Hindu dengan tujuan untuk meningkatkan sradha dan bhakti anak terhadap Ida Sang Hyang Widhi Wasa, meningkatkan kecerdasan, ketrampilan, dalam menjalankan ajaran agama, mempertinggi budi pekerti, memperkuat kepribadian, dan mempertebal semangat kebangsaan dan cinta tanah air.

Parisada Hindu Dharma Indonesia Pusat (1996: 23-24), menyebutkan bahwa pendidikan agama Hindu memberikan tuntunan dalam menempuh kehidupan dan mendidik masyarakat, bagaimana hendaknya berpendirian berbuat atau bertingkah laku supaya tidak bertentangan dengan ajaran dharma, etika dan ajaran Agama Hindu. Agama dapat menyempurnakan manusia dalam meningkatkan hidup baik secara material mapun spiritual. Jadi pendidikan Agama Hindu adalah suatu proses atau upaya membentuk kepribadian utama sesuai dengan nilai-nilai ajaran agama Hindu yang bersumber pada Weda, yang dilakukan secara sengaja maupun tidak sengaja di dalam dan di luar sekolah.

Fenomena yang terjadi sekarang ini dalam hal pendidikan agama Hindu adalah kurangnya tenaga pendidik di sekolah negeri maupun swasta. Sekolah negeri maupun swasta enggan dalam merekrut tenaga pendidik yang beragama Hindu, padahal dalam melaksanakan pendidikan agama harus dilakukan oleh guru yang seagama. Oleh karena itu untuk mengatasi masalah tersebut maka Pasraman sebagai penyelenggara dan pengelola Pendidikan agama Hindu. Mengingat bahwa 
Pendidikan agama sangat penting sesuai dengan Peraturan Pemerintah Republik Indonesia No.55 Tahun 2007 tentang Pendidikan Agama pada pasal 1 disebutkan bahwa "Pendidikan agama berfungsi untuk membentuk manusia Indonesia yang beriman dan bertaqwa kepada Tuhan Yang Maha Esa serta berakhlak mulia dan mampu menjaga kedamaian dan kerukunan hubungan inter dan antar umat beragama”. Dengan demikian keberadaan Pasraman Purna Lingga sebagai salah satu pengelola Pendidikan agama yang berada di Kota Bekasi yang penulis pilih sebagai lokasi dari penelitian ini.

Berdasarkan pengamatan yang penulis lakukan selama ini proses pembelajaran yang dilakukan di Pasraman Purna Lingga dilaksanakan dengan cara diterangkan secara teori di kelas, yang diawali dengan menjalankan materi sambil memberikan catatan, kemudian dilanjutkan dengan memberi contoh-contoh soal dan latihan, serta diakhiri dengan memberi tugas pekerjaan melalui lembaran kegiatan siswa. Padahal banyak metode yang ada yang bisa digunakan dalam proses belajar mengajar. Karena dengan metode pengajaran yang bervariasi peserta didik bisa lebih memahami materi dan mampu mengembangkan bakat serta ketrampilan yang ia miliki.

Dalam melaksanakan pembelajaran seorang pendidik harus cerdas untuk menggunakan model pembelajaran yang tepat dan efektif sesuai dengan kebutuhan siswa, mengingat sistem pembelajaran sekarang ini siswa dituntut aktif, siswa tidak hanya menjadi objek dari pembelajaran saja tetapi siswa menjadi subyek dari pembelajaran yang artinya siswa diberi kesempatan mengembangkan ketrampilan, bakat dan kemampuannya. Guru hanya menjadi fasilitator dalam mengarahkan siswa untuk mengembangkan dirinya. Salah satu syarat untuk menjadi siswa yang aktif, yang paling penting siswa berani berbicara tampil di depan kelas, bertutur kata yang baik. Peserta didik harus sejak dini diberikan pembelajaran mengenai pembentukan karakter karena sikap, etika dan sopan santun harus diamalkan kepada anak didik.

Berdasarkan pengamatan yang peneliti rasakan selama ini dalam proses pembelajaran terdapat beberapa permasalahan mengenai peserta didik diantaranya hanya dengan menggunakan metode ceramah saja sehingga peserta didik jadi kurang percaya diri dalam mengeluarkan pendapatnya di depan kelas. Mereka 
hanya menjadi pendengar saja dan tidak turut aktif dalam pembelajaran. Dalam menggunakan bahasa mereka masih terbiasa dengan bahasa sehari-hari seperti layaknya teman sendiri, hanya satu dua orang saja yang berani berbicara di depan kelas.

Metode ternyata mempunyai andil yang cukup besar dalam kegiatan pembelajaran. Salah satunya yaitu metode Bermain Peran (role playing) adalah bentuk metode mengajar dengan mendramakan atau memerankan cara tingkah laku dalam hubungan sosial. Bermain peran lebih menekankan pada kenyataan dimana para murid diikutsertakan memainkan peranan dalam mendramakan tokoh yang diperankan sesuai dengan karakternya masing-masing (Zuhairini, 1983:102). Dalam hal ini penulis akan mengkaji penerapan metode pembelajaran bermain peran dalam mengembangkan karakter dan kecerdasan linguistik.

Karakter merupakan standar atau norma dan system nilai yang terimplikasikan dalam berbagai bentuk kualitas diri. Karakter dilandasi nilai-nilai luhur yang pada akhirnya terwujud di dalam perilaku. Setiap manusia memiliki sifat yang berbeda-beda sehingga sifat-sifat itulah yang membedakan manusia yang satu dengan manusia yang lainnya. Karakter secara kebahasaan adalah sifat-sifat kejiwaan atau budi pekerti yang membedakan seseorang dari yang lain (Muhammad, 2014:16)

Berdasarkan latar belakang masalah yang ada dan melihat pentingnya suasana belajar yang menyenangkan, maka peneliti tertarik untuk melakukan penelitian tentang metode bermain peran (role playing) diharapkan mampu mengembangkan karakter siswa dan kecerdasan linguistik. Metode ini menggunakan konsep permainan tetapi lebih terarah. Mereka juga masih dapat melakukan gerakan-gerakan atau berjalan-jalan tidak merasa dikekang atau dimarahi tetapi tujuan pembelajaran dapat tercapai. Di samping itu metode ini juga cukup menarik karena dengan metode ini peserta didik bebas berekspresi dan menyampaikan apa yang mereka pikirkan tanpa takut disalahkan. Siswa juga dapat menerima karakter, perasaan dan ide orang lain dalam situasi yang menyenangkan. Dengan demikian maka penulis tertarik untuk mengambil judul skripsi "Penerapan Metode Bermain Peran dalam Mengembangkan Karakter dan Kecerdasan Linguistik di Pasraman Purna Lingga Pondok Gede". Untuk megetahui apakah 
metode bermain peran dapat mengembangkan karakter dan kecerdasan linguistik peserta didik.

\section{Rumusan Masalah}

Berdasarkan latar belakang tersebut maka dapat dikemukakan rumusan masalah sebagai berikut:

a. Bagimanakah penerapan metode pembelajaran bermain peran dalam pembelajaran pendidikan Agama Hindu pada pengembangan karakter dan kecerdasan linguistik pada siswa kelas VIII SMP di Pasraman Purna Lingga Pondok Gede Bekasi?

b. Bagaimana hubungan metode bermain peran dalam pengembangan karakter dan kecerdasan linguistik pada siswa kelas VIII SMP di Pasraman Purna Lingga Pondok Gede Bekasi?

\section{Tujuan dan Manfaaat}

Berdasarkan rumusan masalah yang telah dikemukakan di atas, maka tujuan penelitian ini adalah:

a. Untuk mengetahui penerapan metode pembelajaran bermain peran dalam pembelajaran Pendidikan Agama Hindu pada pengembangan karakter dan kecerdasan linguistik peserta didik di Pasraman Lingga Pondok Gede Bekasi.

b. Untuk mengetahui hubungan antara metode Bermain Peran dalam pengembangan karakter dan kecerdasan linguistik peserta didik Pasraman Purna Lingga Pondok Gede Bekasi.

Sedangkan manfaat dari penelitian ini adalah dapat memberikan referensi pada guru agama Hindu dalam menyampaikan materi dengan menggunakan metode pembelajaran bermain peran agar peserta didik dapat mengembangkan karakter serta penggunaan Bahasa. 


\section{Metodologi Penelitian}

Pengertian metode penelitian menurut yaitu Metode Penelitian secara tersirat dapat memberikan gambaran mengenai pendekatan, tipe, jenis atau desain dari suatu penelitian (Widodo, 2018). Metode penelitian pada dasarnya merupakan cara ilmiah untuk mendapatkan data dengan tujuan dan kegunaan tertentu, Penelitian ini merupakan jenis penelitian kualitatif yang bersifat deskriptif (Sugiono, 2014). Teknik sampling yang digunakan oleh peneliti adalah purposive sample. Purposive sample adalah Teknik penentu sample dengan pertimbangan tertentu (Sugiono, 2014).

Adapun tujuan dari penelitian ini adalah untuk mengungkapkan kejadian atau fakta, keadaan, fenomena, variabel dan keadaan yang terjadi saat penelitian berlangsung dengan menyuguhkan yang sebenarnya terjadi. Penelitian ini menafsirkan dan menguraikan data yang bersangkutan dengan situasi yang sedang terjadi, sikap serta pandangan yang terjadi di Pasrman Purna Lingga.

Selanjutnya data dianalisa dengan cara mereduksi data yang berkaitan dengan data primer maupun data sekunder. Kemudian data diuraikan dalam kalimat-kalimat sehingga membentuk suatu pengertian yang berhubungan dengan masalah yang diteliti.

\section{Hasil dan Pembahasan}

\section{Tahapan Dalam Menyelenggarakan Metode Bermain Peran}

Metode bermain peran (role playing) dikembangkan oleh Fannie Shaftel dan George Shaftel. Bermain peran merupakan suatu model pembelajaran, dimana peserta didik diminta untuk memainkan peran tertentu, terutama yang berkaitan dengan masalah-masalah social. Dalam pengertian sederhana, bermain peran merupakan usaha untuk memecahkan masalah melalui peragaan tindakan (action)(Sutikno, 2014)

Metode ini dapat dipergunakan didalam mempraktekkan isi pelajaran yang baru, mereka diberi kesempatan seluas-luasnya untuk memerankan sehingga menemukan kemungkinan masalah yang akan dihadapi dalam pelaksanaan sesungguhnya. Metode ini menuntutkan guru untuk mencermati kekurangan dari peran yang di peragakan siswa (Yamin, 2005) 
Bermain peran merupakan salah satu model pembelajaran yang diarahkan pada memecahkan masalah-masalah yang berkaitan dengan hubungan antar manusia. Pengalaman belajar yang dari metode ini meliputi, kemampuan kerjasama, komunikatif, dan menginterpretasikan suatu kejadian.

Berdasarkan beberapa penjelasan diatas dapat disimpulkan bahwa metode bermain peran adalah metode pembelajaran sebagai simulasi yang diarahkan untuk mengkreasikan peristiwa sejarah, mengkreasikan peristiwa-peristiwa aktual, atau kejadian-kejadian yang muncul pada masa mendatang.

Dalam melaksanakan metode bermain peran melalui proses atau tahapan yang panjang diantaranya sebagai berikut:

\section{Tahap Perencanaan}

a. Mempelajari dengan cermat kegiatan yang akan disimulasikan dan mencatat bagian-bagian atau langkah-langkah yang akan diperagakan, serta memberikan catatan untuk bagian-bagian utama atau langkah-langkah kunci.

b. Membuat skenario simulasi merujuk kepada topik, dan tujuan pembelajaran serta catatan tentang bagian dan langkah-langkah utama yang telah dibuat pada langkah sebelummnya. Skenario ini meliputi: 1) Alur cerita dan prosedur yang disimulasikan; 2) Berbagai macam peran; 3) Kunci-kunci pokok dari prosedur dan kompetensi yang akan diajarkan beserta standar keberhasilannya.

c. Melakukan uji coba bermain peran serta penyempurnaan skenario simulasi dibuat menjadi skenario akhir yang akan digunakan di kelas.

\section{Tahap Persiapan}

a. Mempersiapkan dan memeriksa kesiapan peralatan serta pendukung lainnya.

b. Menjelaskan kepada peserta didik gambaran umum simulasi dan kaitannya dengan topik yang sedang dipelajari.

c. Menyiapkan skenario simulasi yang telah disempurnakan.

d. Membagikan skenario kegiatan kepada peserta didik sesuai dengan perannya masing-masing dan memberikan penjelasan tentang apa yang harus dan apa yang tidak boleh dilakukan oleh peserta didik. 
e. Memberikan kesempatan kepada peserta didik untuk bertanya untuk memperjelas pemahamannya tentang kegiatan berdrama dan tokoh yang diperankannya.

\section{Tahap Pelaksanaan}

a. Melakukan langkah demi langkah kegiatan simulasi sesuai dengan alur cerita dalam skenario

b. Guru berperan sebagai sutradara yang mengendalikan kegiatan

c. Mengingatkan siswa yang kurang serius agar memfokuskan diri pada kegiatan supaya memberikan makna dirinya dan kelas

d. Guru membuat catatan-catatan tentang hal-hal yang perlu didiskusikan pada akhir pembelajaran yang meliputi hal-hal yang perlu mendapatkan pujian da hal hal yang perlu diperbaiki.

e. Jika waktu masih tersedia, ulangi melakukan langkah demi langkah dengan terlebih dahulu mendiskusikan hal-hal yang perlu diperbaiki. Jika perlu membuat rotasi peran diantara sesama peserta didik untuk meningkatkan keluasan kompetensi dan juga meningkatkan semangat belajar peserta didik.

f. Minat peserta didik menyebutkan urutan langkah demi langkah dengan kecepatan sub-normal dan guru melakukan langkah sesuai dengan urutan yang disebut oleh peserta didik.

4. Tahap Evaluasi dan Penutup

a. Memberikan sejumlah pertanyaan yang terkait dengan bagian atau langkah yang baru diperagakan berdasarkan catatan-catatan yang telah dibuat.

b. Meminta komentar dari peserta didik tentang pelaksanaan langkah-langkah yang dilakukan oleh temannya.

c. Buatlah rangkuman dari kegiatan yang terkait dengan tujuan pembelajara dengan menggalinya dari siswa

Berdasarkan beberapa penjelasan bahwa metode bermain peran ada beberapa tahapan dan melalui proses yang Panjang. Metode bermain peran tersebut diterapkan dengan model pembelajaran Project Base Learning dimana peserta didik bersama guru membuat naskah drama lalu dipresentasikan atau ditampilkan dengan 
memerankan naskah yang telah dibuat. Dalam hal ini yang dijadikn pedoman yaitu mengenai cerita yang mengandung sejarah yaitu cerita Ramayana.

\section{Bermain Peran dalam Mengembangkan Karakter}

Menurut Tadziroatun Musfiroh (2008) karakter mengacu pada serangkaian sikap (attitude), perilaku (behaviors), motivsi (motivation), dan ketrampilan (skills). Makna karakter berasal dari Bahasa Yunani "to mark" atau menandai dan memfokuskan pada aplikasi nilai kebaikan dalam bentuk tindakan atau tingkah laku, sehingga orang yang tidak jujur, kejam, rakus, dan berperilaku jelek dikatakan sebagai orang yang berkarakter jelek. Sebaliknya aorang yang berperilaku sesuai dengan kaidah moral dinamakan berkarakter mulia (Isna, 2011)

Seorang anak mempunyai karakter yang baik bila menerapkan nilai-nilai yang baik dalam kehidupannya. Peserta didik dianggap memiliki karakter mulia apabila ia mempunyai pengetahuan yang mendalam tentang potensi dirinya serta mampu mewujudkan potensi itu dalam sikap dan tingkah lakunya. Hal ini senada diungkapkan juga oleh Pearson \& Nicholson (2000) bahwa dimilikinya karakter yang baik dan positif akan menghubungkan 3 aspek dalam hidup anak, yaitu dirinya sendiri, orang lain, dan komunitas/masyarakat luas. Dengan dirinya sendiri, anak yang memiliki karakter positif dapat menunjukkan perilaku mandiri, gigih, dan banyak akal. Sedangkan dengan orang lain dan masyarakat luas, anak yang memiliki karakter positif seperti berani dan adaptif terhadap perbedaan-perbedaan yang ada.

Nilai-nilai karakter dasar yang harus diajarkan kepada peserta didik sejak dini adalah sifat dapat dipercaya, rasa hormat dan perhatian, peduli, jujur, tanggung jawab, ketulusan berani, tekun, disiplin, dan adil. Dalam rangka menyelenggarakan pendidikan karakter, sangat penting bagi guru untuk senantiasa melibatkan peserta didiknya dalam berbagai kegiatan yang dapat memancing responnya terhadap kegiatan tersebut. Oleh karena itu pendidikan karakter adalah mengajar peserta didik tentang nilai-nilai dasar kemanusiaan termasuk kejujuran, kebaikan, kemurahan hati, keberanian, kebebasan, kesetaraan dan penghargaan kepada orang lain. (Muhammad, 2014:10) 
Dalam hal ini karakter dari siswa tersebut sudah berkembang dengan baik. seperti yang telah dijelaskan oleh Simon Philips karakter adalah kumpulan tata nilai yang menuju pada suatu sistem, yang melandasi pemikiran, sikap dan perilaku yang ditampilkan(Mu'in, 2016)

Sikap ramah, sopan santun, dalam berbicara kepada guru merupakan cermiman dari Tri Kerangka Dasar Agama Hindu yaitu terdapat pada Susila. Menurut Yuda Triguna dalam bukunya "Swastikarana" (2013: 127), Susila adalah tingkah laku manusia yang baik dan terpancar sebagai cerminan objektif kalbunya dalam berinteraksi dengan lingkungan.

Tujuan dari sebuah pembelajaran adalah adanya hasil yang terlihat salah satu yaitu perubahan tingkah laku. Dalam hal tingkah laku setiap peserta didik sangat berbeda dengan satu yang lainnya tetapi dengan sebuah pendidikan diharapkan untuk berubah menjadi yang lebih baik. Tingkah laku yang baik yang perlu dikembangkan antara lain sikap peduli terhadap sesama teman, orang tua, dan kepada guru maupun adik tingkat. Sikap bertanggung jawab terhadap apa yang diperbuat. Jujur terhadap diri sendiri dan orang lain. Disiplin terhadap peraturan yang ada di sekolah. Kreatif, mandiri, berfikir kritis, percaya diri, gigih. Peserta didik di Pasraman Purna Lingga sudah mengembangkan karakternya dengan baik yaitu adanya sikap kreatif dan banyak akal dalam proses pembelajaran, sikap saling menghargai dan menghormati guru-guru pasraman, serta saling menolong teman maupun guru di lingkungan pasraman. Pengembangan karakter harus dilakukan setiap hari agar menjadikan terbiasa dan mengubah tingkah laku sebagai hasil dari proses pembelajaran. Seperti yang telah dijelaskan sebelumnya bahwa karakter tersebut dapat diarahkan menuju lebih baik lagi. karena pada dasarnya karakter merupakan pembawaan seseorang dan dapat dirubah melalui proses pembelajaran serta lingkungan dimana mereka berinteraksi. Istilah karakter dianggap sama dengan kepribadian, yaitu ciri atau karakteristik atau gaya sifat khas dari seseorang. Setiap manusia mempunyai karakter yang berbeda-beda yang bersumber dari bentukan-bentukan yang diterima dari lingkungan misalnya keluarga pada masa kecil, dan juga bawaan dari seseorang sejak lahir. Senada dengan yang diungkapkan oleh William Stem mengenai teori konvergensi yang berbunyi "pembawaan dan lingkungan keduanya menentukan perkembangan manusia” (Purwanto, 2000). 


\section{Metode Bermain Peran untuk Mengembangkan Kecerdasan Linguistik}

Pada sistem pembelajaran saat ini yang difokuskan adalah student center dimana siswa sebagai subjek dari pembelajaran. Dalam hal ini peserta didik dituntut untuk berani tampil serta mengungkapkan pendapatnya. Dalam menuangkan pendapat itu hal yang mendasar adalah berani berbicara di depan kelas, maupun dalam berdiskusi. Dimana peserta didik harus mampu mengolah kata, bahasa maupun pembawaan dalam berbicara. Untuk itu kecerdasan linguistik penting untuk dilatih dalam proses pembelajaran terutama tingkat menengah dimana mereka harus bisa menyampaikan pesan itu secara komunikatif. Seorang pembicara dapat memanfaatkan tinggi rendag suara atau tekanan, air muka, gerakan tangan atau isyarat untuk mengungkapkan ide, sehingga si penerima bahasa lisan lebih mudah mengerti dan lebih memahami apa yang ingin disampaikan oleh si pembicara (Dibia, 2016)

Hal ini senada yang diungkapkan oleh Edward Sapir menyatakan bahwa bahasa adalah murni kemanusiaan dan merupakan jalur non-instingtif untuk mengkomunikasikan ide, emosi, kehendak, harapan dan cita-cita dengan memanfaatkan secara sengaja system yang dihasilkan oleh isyarat-isyarat bahasa dan kebahasaan(Ridwan, 1999)

Kecerdasan linguistik yang penulis kaji yaitu mengacu pada naskah drama yang diperankan oleh peserta didik yaitu bagimana ekspresi wajah yang ditampilkan, intonasi, dan kecakapan dalam menggunakan bahasa. Seperti yang diungkapkan oleh Finnocchiaro (1974:3) mengatakan bahasa adalah suatu system symbol vokal yang arbitrer yang memungkinkan sekelompok orang dalam lingkup kebudayaan tertentu, atau kelompok orang lainnya yang mempelajari lingkup kebudayaan tersebut untuk saling berkomunikasi dan berinteraksi.

Dengan demikian sebagian besar peserta didik sudah baik untuk menumbuhkan kecerdasan linguistik sependapat apa yang telah dikatak oleh De Saussure bahwa bahasa diungkapkan melalui dua bagian kegiatan yaitu bagian luar yaitu mulut dan telinga sedangkan bagian dalam yaitu akal pikiran. Seseorang mampu berkomunikasi atau menangkap bahasa melalui dua unsur tersebut yaitu fisik dan insting. Hal ini menandakan bahwa peserta didik telah mengungkapkan 
akal tau pikiran yang dikelurkan lewat mulut lalu diterima melalui pendengaran untuk mengolah bahasa.

\section{Hubungan Metode Bermain Peran dalam Mengembangkan Karakter dan Kecerdasan Linguistik}

Penerapan metode bermain peran untuk mengembangkan karakter juga terdapat hubungan dalam mengembangkan kecerdasan linguistik. Bahwasanya ketika seseorang itu lancar dan tepat dalam berbahasa, baik dalam mengucapkan intonasi, mempunyai ekspresi muka dalam berbicara serta fasih dalam mengungkapkan setiap kata atau kalimat diartikan ia telah terampil dalam berbicara. Terampil dalam berbicara termasuk ke dalam bentuk dari karakter. Hal ini senada dengan pendapat yang dikemukakan oleh Tarigan (2015:16) bahwa berbicara adalah kemampuan untuk mengucapkan bunyi-buunyi artikulasi atau kata-kata untuk mengekspresikan, menyatakan atau menyampaikan pikiran, gagasan dan perasaan. Bahwasanya ketika seseorang berbicara ia mengungkapkan apa yang ada di fikiran, ide-ide yang ada dalam akal dikeluarkan melalui bunyi bahasa. Dengan terampil berbicara maka peserta didik menjadi percaya diri untuk tampil di depan kelas maupun untuk menyatakan pendapatnya. Siswa yang memiliki ketrampil adalah siswa yang berkarakter. Sedangkan dalam hal kecerdasan linguistik siswa akan membaca serta menyuarakan dari bahasa yang ada dalam naskah drama mengenai kisah Ramayana dengan terus berlatih maka siswa akan lancar dalam berbahasa terutama Bahasa Indonesia yang disertai dengan ekspresi atau mimik muka, intonasi, lafal dan kefasihan dalam mengungkapkan bunyi bahasa.

Dengan memahami konten yaitu naskah drama maka peserta didik akan mengetahui karakter dari setiap tokoh Ramayana, peserta didik bisa merasakan dan menerapkan dalam drama tersebut. Oleh karena itu sesudah melakukan drama maka peserta didik akan mengamalkan sifat maupun karakter dari tokoh-tokoh baik yang diperankan. Dengan demikian akan membentuk kepribadian siswa menjadi lebih baik lagi. Para siswa memerankan secara langsung tokoh-tokoh yang ada di cerita Ramayana mereka bisa menerapkan karakter-karakter yang baik dalam kehidupan sehari-hari. 
Peserta didik lebih terlatih dalam membaca dan memahami konten sehingga berdampak positif pada pribadi anak dan juga kemampuan berbicara yang baik, ketika ia memahami konten maka akan berani berbicara dan lancar dalam menggunakan bahasa. peserta didik serta mengembangkan kecerdasan linguistik siswa SMP kelas VIII Pasraman Purna Lingga. Dengan cara memerankan tokohtokoh dalam kisah Ramayana maka peserta didik lebih memahami serta mengetahui dari karakter setiap tokoh. Dan dapat melakukan hal-hal yang baik serta meninggalkan hal yang buruk.

Dalam hubungannya dengan kecerdasan linguistik tentunya berpengaruh karena dengan metode cerita atau bermain peran siswa dapat menampilkan di depan kelas dan dapat menyampaikan pesan positif. Mereka dapat berlatih berbicara yang benar yaitu mengenai intonasi, lafal, kefasihan serta mimik muka yang ditampilkan.

Penerapan metode bermain peran sebagian besar dari siswa kelas VIII SMP Pasraman Purna Lingga untuk mengembangkan karakter secara keseluruhan sudah berkembang dengan baik sedangkan untuk kecerdasan linguistik juga sudah meningkat tetapi ada 3 siswa yang belum optimal dalam hal berbicara, mereka kurang percaya diri dalam mengungkapkan pendapatnya. Tetapi dari hasil penelitian yang diperoleh bahwa metode ini tepat untuk diterapkan.

Berdasarkan hasil yang diperoleh dalam menerapkan metode bermain peran tersebut menghasilkan perubahan tingkah laku setelah mendapatkan pembelajaran, pengalaman dan pengetahuan tentang karakter dari yang kurang baik menjadi lebih baik lagi seperti yang dijelaskan oleh Thobroni (2013:17) juga mengemukakan pendapatnya pembelajaran adalah pemerolehan suatu mata pelajaran atau memperoleh suatu ketrampilan melalui pelajaran, pengalaman, atau pengajaran yang menghasilkan perubahan tingkah laku

\section{Kesimpulan}

Dari hasil penelitian mengenai penerapan metode bermain peran dapat disimpulkan sebagai berikut:

a. Penerapan metode bermain peran melalui empat tahap yaitu perencanaan, persiapan, pelaksanaan dan penutup. Guru sebagai sutradara dalam metode bermain peran yang mengatur dari jalannya drama yang ditampilkan. Tahap 
perencanaan dimulai dengan membuat naskah drama, mempelajari materi dari cerita yang terdapat di naskah, tahap perencanaan yaitu membagikan naskah kepada peserta didik dan menjelaskan alur ceritanya, tahap pelaksanaan yaitu mulai memerankan drama sesuai dengan aturan yang telah dijelaskan sedangkan tahap evaluasi yaitu mengevalusi hal-hal yang kurang selama berdrama dan memberi masukan serta penilaian. Penerapan metode bermain peran mengambil dari kisah Ramayana untuk mengembangkan karakter peserta didik dimana setiap peserta didik harus memahami serta menghayati peran yang dimainkan. Setelah melakukan drama peserta didik bisa menyimpulkan karakter baik yang diterapkan dalam kehidupan sehari-hari. kecerdasan linguistik diambil dari bagaimana peserta didik memerankan tokoh yaitu menjiwai karakternya serta bisa berbahasa dengan baik, memahami intonassi, mimik muka, lafal serta kefasihan dalam berbicara, sebagian besar peserta didik sudah mampu untuk menerapkan hal tersebut.

b. Dalam hubungannya bermain peran dan kecerdasan linguistik yaitu salingberjalan beriringan, ada hubungan yang baik ketika siswa mempunyai karakter atau pribadi yang baik maka ia juga terampil dalam berbicara, memilih bahasa yang baik dan benar serta mengekspresikan wajah sesuai dengan yang dikatakan. 


\section{DAFTAR PUSTAKA}

Dibia, K. (2016). Bahasa Indonesia untuk Perguruan Tinggi. Depok: PT Raja Grafindo Persada.

Isna, N. (2011). Panduan Menerapkan Pendidikan Karakter di Sekolah. Yogyakarta: Laksana.

Mu'in, F. (2016). Pendidikan Karakter: Konstruksi Teoritik dan Praktik. Yogyakarta: Ar-ruz Media.

Ridwan. (1999). bahasa dan liguistik. jakarta: PT Mestika.

Sugiono. (2014). Metode Penelitian Kuantitatif \& Kualitatif, Dan R\&D. Bandung: Alfabeta.

Sutikno, S. (2014). Metode dan Model-Model Pembelajaran. Lombok: Holistika.

Widodo. (2018). Metodologi Penelitian Populer dan Praktis. Depok: PT. Rajagrafindo Persada.

Yamin, M. (2005). Strategi Pembelajaran Berbasis Kompetensi. jakarta: Gauang Persada Pers. 